\title{
DAMPAK PROGRAM REKLAMASI BAGI EKONOMI RUMAH TANGGA NELAYAN DI KOTA MANADO
}

\author{
Max Wagiu \\ Program Studi Agro Bisnis Perikanan, \\ Fakultas Perikanan dan IImu Kelautan. UNSRAT. Manado 95115.
}

\begin{abstract}
This study focused on the economic and the social impacts of the reclamation program for the traditional fishermen who live along the coastal area of Manado City set the reclamation program, particularly Wenang Selatan, Titiwungen, and BahuMalalayang, using direct observation and guided interview techniques to selected respondent.

The results found that in economic aspect, the local people gained higher income before reclamation than after it; in social aspect, the former fishermen had to alter their profession to the one they did not know or were sent outside the city, even far from social facilities, such as school, health services, etc.
\end{abstract}

Keywords : Reclamation, fishermen, social, economic aspect.

\section{PENDAHULUAN}

Indonesia, sebagai negara kepulauan, secara tetap senantiasa dihadapkan pada problem abrasi pantai. Di pantai utara pulau Jawa, Sumatera, Sulawesi, Maluku dan pulau-pulau lain di Indonesia bagian Timur, abrasi pantai merupakan fenomena yang terus menerus terjadi.

Selama ada angin yang memicu terjadinya ombak dan gelombang laut, pengikisan garis pantai akan terus menerus berlangsung tanpa henti.

Beberapa upaya ditakukan untuk memperoleh kembali bagi pantai yang hilang, diantaranya dengan melakukan reklamasi.

Menurut Peterson (2005), reklamasi diartikan sebagai upaya pengadaan lahan dengan cara mengeringkan rawa, daerah pasang surût dán sebagainya.

Dalam tulisan ini, penulis mendefinisikan reklamasi sebagai kegiatan untuk memperoleh kembali tanah yang hilang akibat abrasi di daerah pesisir pantai.

Abrasi adalah hilangnya sebagian daerah pesisir akibat terjangan gelombang laut yang menghancurkan tanah daratan di pesisir pantai. Ini merupakan proses alam yang mencari keseimbangan baru akibat kerusakan lingkungan kawasan pantai, antara laut dan daratan, yang diakibatkan oleh berbagai hal seperti punahnya hutan mangrove dan rusaknya terumbu karang yang sebenaŕnyå menjadi benteng bagi perlindungan garis pantai.

Ada 3 tujuan dari program reklamasi adalah:

a) Untuk mendapatkan kembali tanah yang hilang akibat terjangan gelombang laut.

Untuk memperoleh tanah baru di kawasan depan garis pantai untuk mandirikan bangunan yang akan difungsikan sebagai benteng perlindungan garis pantai.

c. Untuk alasan ekonomis, pembangunan atau untuk mendirikan konstruksi bangunan dalam skala lebih besar.

Tujuan ekonomisnya adalah untuk membangun pemukiman baru atau kompleks perdagangan seperti yang terjadi di kawasan Boulevard Manado.

Bagi komunitas nelayan tradisional, ada 3 dampak dari reklamasi bagi kehidupan mereka, yakni:

\section{Dampak Fisik}

Dampak fisik terjadi karena adanya perubahan lingkungan. Berdirinya bangunan konstruksi di daerah pantai yang direklamasi, membawa perubahan arus laut, yang berakibat menjauhnya ikan yang tadinya berdiam dan mencari makanan di kawasan reklamasi. Akibat lebih jauh, komunitas nelayan tradisional yang biasanya mencari dan menangkap ikan di kawasan tersebut, 
harus bertolak lebih jauh dalam usaha mencari dan menangkap ikan.

\section{Dampak Sosial}

Dampak sosial terjadi karena dengan berdirinya bangunan konstruksi di kawasan reklamasi, komunitas nelayan di daerah tersebut terpaksa pindah ke tempat lain, karena 2 alasan penting:

- Mereka terpaksa menjual tanah tempat mereka bermukim karena tidak dapat lagi menjalankan profesinya seperti biasa dan juga karena tertarik dengan harga tanah yang meningkat.

- Mereka tidak dapat berinteraksi dengan orang baru yang menempati kawasan reklamasi yang modern dan yang pasti ada jurang perbedaan yang dalam di antara masyarakat komunitas nelayan tradisional dengan para pendatang baru akibat orientasi sosial yang berbeda. Pindah ke pemukiman baru akan selalu membawa dampak bagi kehidupan sosial terutama anak-anak yang perlu membangun suatu kehidupan sosial yang baru dan masih asing bagi mereka. Belum lagi jika tidak tersedianya fasilitas pelayanan sosial di pemukiman yang baru, seperti sekolah, tempat ibadah, kesehatan, listrik, telepon dan ber bagai hal yang diperlukan bagi kêhidupan sosial yang minimal.

\section{Dampak Ekonomi}

Dampak ekonomi, terutama terjadi pada tingkat pendapatan kéluarga. Perubahan daerah pemukiman, pasti tidak selalu menjamin kelangsungan profesinya sebagai nelayan karena mungkin kawasan pemukiman yang baru itu jauh dari pantai. Kalau hal ini terjadi, pasti sulit melangsungkan profési nelayan dimana laut seakan sudah menjadi satu dengan kehidupan nelayan. Hal ini membawa kekacauan dalam kehidupan ekonomi keluarga, akibat bertempat tinggal di kawasan pemukiman yang kurang kondusif bagi kehidupan sebagai nelayan. Mengubah profesi tentu memerlukan waktu yang lama.

Di kota ini, sebagai kota yang kondisi geografinya terletak di tepi pantai, banyak nelayan tradisional yang sehari-hari menggantungkan hidup dari pantai dan laut.
Dengan demikian, penelitian ini bertujuan untuk mengetahui seberapa jauh program reklamasi di kota Manado telah mempengaruhi kehidupan ekonomi keluarga nelayan yang berdiam di sekitar kawasan reklamasi.

\section{METODOLOGI PENELITIAN}

Penelitian ini dilakukan pada 3 kelurahan di pantai kota Manado, yaitu Wenang Selatan, Titiwungen dan Bahu.

Penelitian ini menggunakán métode deskriptif berdasarkan pendekatan studi kasus. Data primer diperoleh melalui pengamatan langsung dan wawapcara dengan para nelayan yang dijadikan sampel melalui kuisioner dengan opsijawaban menggunakan teknik skala interval (Sudjana, 1974). Data sekunder diperoleh dari berbagai instansi dan berbágai referensi yang berkaitan dengan topikpenelitian.

Dari 153 keluarga nelayan di kota Manado, telah dipilih secara acak $20 \mathrm{ke}$ luargâ dári 35 keluarga nelayan di Kelurahan-Bahu, 20 keluarga dari 63 keluarga di Kelurahan Wenang Selatan, dan 20 keuarga dari 55 keluarga di Kelurahan 'Titiwungen. Jumlah sampel adalah 60 keluarga nelayan atau $39,2 \%$ dari populasi keluarga nelayan di kota Manado.

Data yang diperoleh, setelah ditabulasi dan dimasukkan ke dalam tabel-tabel kerja, dianalisis secara statistik dengan menggunakan perangkat lunak statistik SPSS 13.0.

Sesuai dengan tujuan penelitian, yakni mengetahui dampak reklamasi terhadap kehidupan ekonomi keluarga nelayan di bidang pendapatan, maka 3 buah hipotesa diuji dengan menggunakan uji statistik pada taraf nyata $5 \%$.

Ketiga hipotesa itu adalah:

1. Program reklamasi tidak berpengaruh secara signifikan pada tingkat pendapatan nelayan.

2. Secara rata-rata, produksi hasil tangkapan ikan oleh nelayan tidak berbeda secara signifikan antara waktu sebelum dan sesudah reklamasi.

3. Terdapat korelasi antara tingkat pendidikan dengan tingkat pendapatan nelayan di kawasan reklamasi. 


\section{HASIL DAN PEMBAHASAN}

\section{Gambaran umum nelayan di kawasan reklamasi}

Luas kawasan yang direklamasi adalah 48 ha yang dilakukan oleh 4 pengembang, yaitu PT. Megasurya Nusa Lestari (15 ha), PT. MultiCipta Perkasa Nusantara (24 ha), PT. Bahu Cipta Persada (7,5 ha) dan PT. Papetra Perkasa Utama (1,5 ha).

Di wilayah reklamasi tersebut, bermukim sejumlah nelayan tradisional dengan alat tangkap yang sederhana seperti pada Tabel 1 berikut ini.

Tabel 1. Jumlah nelayan dan jenis alat tangkap di kota Manado

\begin{tabular}{|c|c|c|c|c|c|c|}
\hline \multirow[b]{2}{*}{ Kelurahan } & \multicolumn{2}{|c|}{ Jumlah Nelayan (KK) } & \multirow[b]{2}{*}{$\begin{array}{c}\text { Sampel } \\
\text { (KK) }\end{array}$} & \multirow[b]{2}{*}{$\begin{array}{c}\text { Jenis alat } \\
\text { tangkap }\end{array}$} & \multicolumn{2}{|c|}{ Jumlah alat tangkap } \\
\hline & $\begin{array}{l}\text { Sebelum } \\
\text { Reklamasi }\end{array}$ & $\begin{array}{l}\text { Sesudah } \\
\text { Reklamasi }\end{array}$ & & & $\begin{array}{l}\text { Sebelum } \\
\text { Reklamasi }\end{array}$ & $\begin{array}{r}\text { Sesudah } \\
\text { Reklamas }\end{array}$ \\
\hline Wenang & 63 & 47 & 20 & Pancing noru & 15 & 18 \\
\hline Selatan & & & & Soma dampar & $\begin{array}{l}3 \\
2\end{array}$ & \\
\hline Titiwungen & 55 & 23 & 20 & $\begin{array}{l}\text { Pancing noru } \\
\text { Soma dampar }\end{array}$ & $\begin{array}{r}12 \\
4\end{array}$ & $\begin{array}{r}16 \\
3\end{array}$ \\
\hline & & & & Soma landra & 4 & \\
\hline Bahu & 35 & 20 & 20 & $\begin{array}{l}\text { Pancing noru } \\
\text { Soma dampar }\end{array}$ & $\begin{array}{r}13 \\
4\end{array}$ & $\begin{array}{r}15 \\
3\end{array}$ \\
\hline & & & & Soma landra & 3 & 2 \\
\hline
\end{tabular}

Peneltian yang difokuskan pada dampak sosial ekonomi reklamasi terhadap masyarakat nelayan tradisional ini yang berjumlah $153 \mathrm{KK}$, dengan menguji 3 hipotesa yang telah dilakukan di atas, ternyata:

1. Reklamasi pantai Manado berpengaruh secara nyata pada tingkat pendapatan nelayan, di ketiga kelurahan sebagai populasi penelitian $\left(t_{\text {hit }}>t_{\text {tab }}\right)$.

2. Terdapat perbedaan nyata dalam jumlah rata-rata jumlah hasil tangkapan ikan di ketiga kelurahan yang menjadi penelitian $\left(t_{\text {hit }}>t_{\text {tab }}\right)$ bagi nelayan yáng menggunakan alat tangkap soma dampar sebelum dan sesudah rekJamsi, tapi sebaliknya tidak terdapat perbedaan yang nyata $\left(\mathrm{t}_{\mathrm{hit}}>\mathrm{t}_{\mathrm{tab}}\right)$ dari rata-rata tangkapan ikan menggunakan soma landra sebelum dan sesudah reklamaśi.

3. Analisis korelasi tiap jenis alat tangkap dengan hasil tangkapan ternyata hanya alat tangkap soma dampar yang berkorelasi secara kuat $(\pi=0,70)$ terhadap pendapatan nelayan, sedangkan alat tangkap pancing noru tidak cukup kuat $(\pi=0,37)$ dan terhadap alat pancing soma landra tidak terdeteksi.

Hasil analisis ini, menandakan bahwa hanya alat tangkap soma dampar (pukat pantai) yang secara positif memberi hasil tangkapan yang berpengaruh positif dan efektif bagi kehidupan nelayan di ketiga kelurahan yang menjadi populasi penelitian sedangkan alat pancing noru (pancing ulur) dan soma landra (jaring insang) tidak cukup efektif.

Penggunaan alat tangkap soma landra tidak cukup efektif dalam menunjang produksi hasil tangkapan ikan karena penggunaan jaring ini sebelum dan sesudah reklamasi terjadi penurunan dari 9 unit menjadi 4 unit. Begitu pula hasil tangkapannya menurun, dari $39.740 \mathrm{~kg}$ menjadi $24.000 \mathrm{~kg}$.

Hasil tangkapan nelayan yang menggunakan alat tangkap soma dampar, menurun dari $44.528 \mathrm{Kg}$ sebelum reklamasi menjadi $28.808 \mathrm{Kg}$ sesudah reklamasi atau berkurang $34 \%$. Hal ini dikarenakan berkurangnya kawasan pantai yang tadinya digunakan sebagai daerah tangkapan alát tangkap ini akibat program reklamasi,

Selanjutuya penelitian ini mendapati penggunaar alat tangkap pancing noru, mengalami penurunan sebesar $17,5 \%$ dari 1.940 $\mathrm{Kg}$ sebelum reklamasi menjadi $1.600 \mathrm{Kg}$ sesudah reklamasi namun analisis satistika tidak menunjukkan perbedaan yang nyata dari kedua periode $\left(t_{t a b}>t_{\text {hit }}\right)$.

Menurunnya jumlah tangkapan pancing noru ini secara kuantitatif akibat:

1. Perubahan lingkungan kawasan garis pantai oleh reklamasi menyebabkan berubahnya habitat ikan di daerah tangkapan.

2. Ikan-ikan semakin menjauh dari daerah tangkapan nelayan.

Akibat reklamasi, pendapatan nelayan mengalami penurunan yang sangat berarti dari Rp. 22.753.500 sebelum reklamasi menjadi Rp. 9.631 .500 per nelayan per tahun sesudah reklamasi. Hal itu digambarkan pada Tabel 2.

Penurunan tingkat pendapatan ini dikarenakan menurunnya hasil tangkapan akibat perubahan yang terjadi dihabitat dikawasan pantai reklamasi. Konsentrasi ikan semakin jauh ke arah laut dalam. Akibat reklamasi telah terjadi perubahan arus yang mempengaruhi iklim habitat ikan dimana tadinya terdapat terumbu karang tempat ikan bertelur dan mencari makan. Bagi nelayan yang hanya mengandalkan perahu tanpa motor dan alat tangkap pancing noru, soma landra dan soma dampar yang tergolong alat tangkap tradisio- 
nal, reklamasi akan berpengaruh pada hasil tangkapan dan tingkat pendapatan.

\begin{tabular}{|c|c|c|c|}
\hline \multirow{2}{*}{ Kelurahan } & \multicolumn{2}{|c|}{$\begin{array}{l}\text { Pendapatan Nelayan } \\
\text { per-Tahun (Rp) }\end{array}$} & \multirow{2}{*}{$\begin{array}{c}\text { Penurunan } \\
\%\end{array}$} \\
\hline & $\begin{array}{l}\text { Sebelum } \\
\text { Reklamasi }\end{array}$ & $\begin{array}{l}\text { Sesudah } \\
\text { Reklamasi }\end{array}$ & \\
\hline $\begin{array}{l}\text { Wenang } \\
\text { Selatan }\end{array}$ & 6.506 .500 & 2.904 .000 & 55,37 \\
\hline Titiwungen & 8.943 .000 & 3.283 .500 & 63,28 \\
\hline $\begin{array}{l}\text { Bahu- } \\
\text { Malalayang }\end{array}$ & 7.304 .000 & 3.444 .000 & 52,85 \\
\hline Jumlah & $\begin{array}{l}22.763 .500 \\
7584500\end{array}$ & 9.631 .500 & 57,67 \\
\hline
\end{tabular}

Pengoperasian perahu tanpa motor dan penggunaan alat tangkap pancing noru, soma landra dan soma dampar oleh para nelayan kurang efektif bagi perolehan hasil tangkapan ikan, karena:

1. Konsentrasi ikan yang telah menjauh dari daerah tangkapan setelah reklamasi sulit dijangkau dan sulit dideteksi kebenarannya dengan penggunaan perahu tanpa motor dan alat tangkap tradisional berupa pancing noru, soma landra, dan soma dampar.

2. Kawasan pantai yang sebelum direklamasi menjadi pendaratan ikan, bagi pengguna soma dampar telah direklamasi menjadi daerah perdagangan sehingga tidak mungkin lagi digunakan.

3. Karena perubahan-perubahan pada poin 1 dan 2, motivasi para nelayan untuk melaut berkurang.

Dampak sosial ekonomi yang terjadi sesudah reklamasi bagi keluarga nelayan tradisional:

1. Berkurangnya produksi tangkapan yang berimbas pada penurunan tingkat pendapatan menimbulkan turunnya kesejahteraan êkonomi dan sosial keluarga nelayam. Untuk mencukupi kebutuhan hidup keluarga banyak nelayan yang harus beralih profesi menjadi buruh harian di proyek konstruksi tanpa keahlian di bidang konstruksi sehingga mereka berstatus sebagai pekerja lepas.

2. Ada keluarga nelayan yang terpaksa pindah ke tempat lain (umumnya di pinggir kota) yang minim sarana pelayanan sosial seperti sekolah untuk anak-anak, fasilitas kesehatan, fasilitas listrik dan yang terpenting mereka harus merubah komunikasi sosial di tempat yang baru, harus menjalani kehidupan sosial yang sama sekali berbeda dari yang dijalani di tempat bermukim semula. Akibatnya mereka dapat mengalami cultural shock akibat perubahan dalam kehidupan sosialnya.

Ada keuntungan ekonomis dari program reklamasi, antara lain:

1. Terbukanya banyak lapangan kerja oleh adanya investasi.

2. Efek multiplier dari investasi akan meningkatkan kesejahteraan ekónomi masyarakat pada umumnya.

3. Meningkatkan pendapatan aslidaerah.

4. Membuka perkembangan sektor pariwisata.

Namun intangible puiblic cost yang harus dibayar perlu diperhitungkan akibat dampak reklamasi bagi'keluarga nelayan yang sudah bermukim di kawasan lingkungan reklamasi.

\section{KESIMPULAN}

Reklamasi yang dilakukan di kawasan pantai Manado membawa dampak sosial, fisik lingkungan, dampak ekonomi dan budaya bagi masyarakat nelayan tradisional di kota Manado, khususnya yang bermukim di Kelurahan Wenang Selatan, Titiwungen dan Bahu Malalayang.

Di samping keuntungan ekonomis yang dapat dinikmati oleh masyarakat, juga ada social cost yang harus diperhitungkan dalam setiap kajian program.

Reklamasi kawasan pantai di kota Manado telah mengakibatkan menurunnya tingkat pendapatan yang berdampak langsung pada kehidupan ekonomi sosial masyarakat nelayan.

\section{DAFTAR PUSTAKA}

Anonimous, 1974. How to Treatment the Beach Abration, Foreshore Protection, Australia.

Nanapriatna dan Setiawan, R. 2005. Pengantar Statistika, Graha IImu.

Petterson, Y.MA. 2005. Kamus Lengkap Inggris Indonesia, Karya Agung, Surabaya.

Rangkuti, F. 2000. Bussiness plan, Gramedia Pustaka Utama, Jakarta. 
Tampi, I. 2000. Dampak Reklamasi Pantai Manado Terhadap Pendapatan Masyarakat Nelayan di Kelurahan Wenang Selatan, Titiwungen, dan Bahu, Fakultas Perikanan dan IImu Kelautan Unsrat, Manado, 2000
Teguh, W. 2004. Cara mudah melakukan analisis statistik dengan SPSS, Gaya Media, Salatiga.

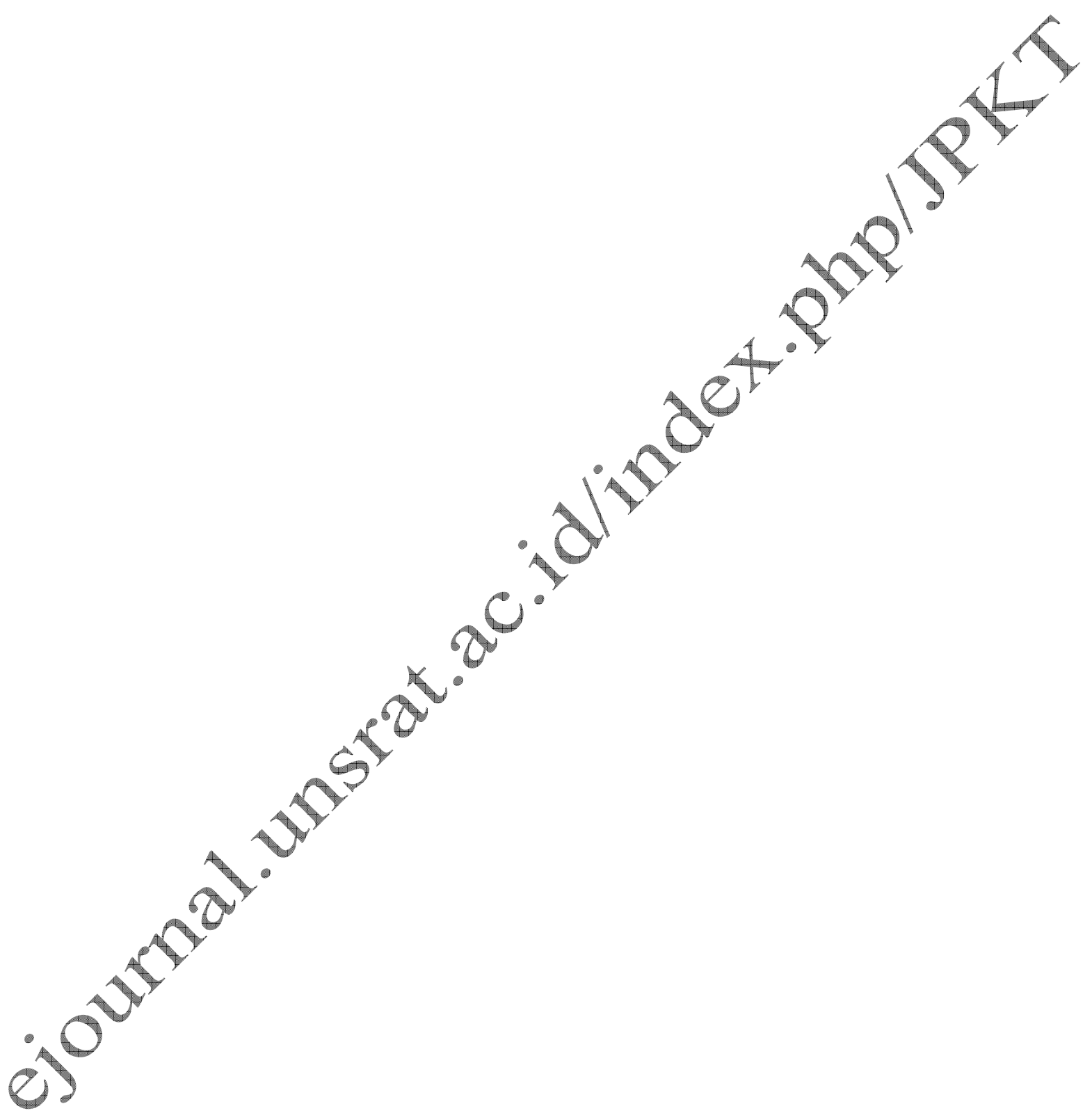

